\title{
オオムギ斑葉モザイク病罹病植物の寒天ゲル中 沈降反応による抗原分析
}

\author{
村 山 大 記* ・横 山 竜 夫* \\ Daiki Murayama and Tatsuo Yokoyama : Analysis of antigens in the plants \\ infected with barley stripe mosaic virus using the gel-diffusion method.
}

\section{I. 緒言}

前報7,9) にて報告したごとく, barley stripe mosaic virus (BSMV) はその抗血清と寒天ゲル中に抹いて反 応し沈降帯を生ずる。筆者らが 3 種の奇主植物より得 た純化法を異にするウイルス汁液を用いて家東に注射 し, 得られた抗血清に対して吸収試験を行なつて, 寒 天ゲル中沈降反応による抗原分析を試みた結果, 罹病 植物泆液を抗原とした場合, ウイルスに由来する沈降 帯のほかに, 正常植物タンパクに由来するものと考え られる沈降带を認めた。すなわち，ウイルスの純化に 硫安塩析法を用いた場合には，正常植物タンパクに由 来する抗原抗体系がかなり多く認められたが，分画遠 心法を行なつた場合にも少数の沈降帯が認められた。 ウイルスの純化を行ない抗血清の調製を行なら場合 そ, ウイルス抗原と正常植物タンパク抗原との解析を 行なうことは，ウイルス純化操作上きわめて重要なこ とと考えられる。また純化ウイルスが寒天ゲル中反応 に拉いて単一の沈降带を示さない場合があるといわれ ている ${ }^{1,3,6,11)}$ 。このような観点から吸収血清にて寒天 ゲル中沈降反応を行ない，ウイルス抗原と正常植物タ ンパク抗原との解析を行なつた。植物タンパクの抗原 分析に関しては福島・松井 ${ }^{2)}$, Moorhead $^{5)}$ の 報告が ある。寒天ゲル中沈降反応に関する数式については, 北海道大学応用電気研究所数学部門安藤毅博士の御教 示を得た。ここに澡謝の意を表する。

\section{II. 実験材料および方法}

\section{1. 抗 原}

吸収試験および寒天ゲル中沈降反応に用いた抗原は 罹病オオムギ (DB), 同コムギ (DW), 同トウモロコ シ（DC）拉よびそれらの健全植物(HB， HW および HC) の粗汁液, ならびに沶の打のの分画遠心法によ

* 北海道大学農学部
る純化液 (PDB, PHB， PDW， PHW， PDC および PHC) の12種である。

\section{2. 抗血清}

前報に報告 ${ }^{8,9)}$ した 6 種の抗血清, すなわち， $\mathrm{aB}$, $\mathrm{aW}, \mathrm{aC}, \mathrm{uB}, \mathrm{uW}$ 扰よび $\mathrm{uC}$ 抗血清を用いた。

3. 寒天ゲル中沈降反応

前報9)の通りで女る。

\section{4. 吸収試験}

抗血清 1 に対して抗原 3 の割合に加え，常法によつ て吸収を行ない，その後抗体を十分に吸収したことを 確かめた。

\section{III. 実験結果}

\section{実 験 1}

$\mathrm{aB}, \mathrm{aW}$ 执よび $\mathrm{aC}$ 抗血清をそれぞれ DB，DW， $\mathrm{DC}, \mathrm{HB}, \mathrm{HW}$ および $\mathrm{HC}$ 抗原にて吸収し, 各吸収 血清について交さ反応を行なつた。まず $\mathrm{aB}$ 抗血清 1 に対して DB 抗原 3 を加えて吸収した吸収血清（aBDB）を中心とし，周囲の 6 つの四又に上記 6 種の抗 原をそれぞれ入れた。また $\mathrm{aB}$ 抗血清を $\mathrm{HB}$ 抗原に て吸収した吸収血清（aB-HB）についても同じょうに し, aB-DW, aB-HW, aB-DC 特よび aB-HC の 6 種の吸収血清に対しても同様にして実験を行なつた。

さらに aW 特よび aC 抗血清をそれぞれ上記抗原 にて吸収した吸収血清に対しても同様にして実験を行 なつた。結果はFig. 1〜3の通りである。

aB-DB (Fig. 1, a ) では全く沈降帯の出現が認め られず抗体の完全吸収が認められたが， $\mathrm{aB}-\mathrm{HB}(1, \mathrm{~d})$ では，DB，DW および DC 抗原に対して抗原側に凹 形の弓状沈降帯がそれぞれ 1 本ずつ認められ, 健全才 オムギ抗原によつて吸収されない抗体の存在が認めら れた。またこれらの沈降帯が互いに両端にて融合する ことにより，同一抗原抗体系であると考えられる。

また aB-DW $(1, b)$ ではDB, HB 抗原に対して, 中間部に 1 本の直線状のやや太い沈降帯を生じた。 
aB-HW (1,e) では罹病植物各抗原に対してさらに 1 本ずつの弓状沈降帯を生じた。

aB-DC (1,c) ではオオムギ（B）抗原に対して4 本, コムギ (W) 抗原に対して 3 本の沈降帯が認めら れたが，これらはすべて抗原，抗血清の中間部にある 直線状の沈降帯であつた。aB-HC $(1, f)$ ではこれら の沈降帯とは別に DB, DW 拉よび DC 抗原に対して さらに 1 本の沱降带が認められたが，これはいずれも 弓状で抗原側に近く, 両端に抢いて融合するものであ り同一反応系によるものと思われた。

aW-DB（2，a）ではB抗原と全く反応しなかつた が, W抗原とは少なくとも 2 本, $\mathrm{C}$ 抗原とは 1 本の沈 降帯が抗原, 抗血清の中間部に見られた。上記の沈降 帯に加らるに aW-HB (2, d) では罹病植物各抗原に 対して,さらに 1 本ずつの弓形沈降帯が抗原のすぐ近 く記認められた。

$\mathrm{aW}-\mathrm{DW}(2, \mathrm{~b})$ では完全吸収が認められ，aW$\mathrm{HW}(2, \mathrm{e})$ では罹病植物汁液に対してのみ, 弓形の 沈降帯が 1 本ずつ現われた。

$\mathrm{aW}-\mathrm{DC}(2, \mathrm{c})$ 飞てはB抗原飞 3 本, W抗原飞 4 本 の沈降帯が中間部に見られ, $\mathrm{aW}-\mathrm{HC}(2, f)$ では中間 部の直線状沱降带の他に 1 本ずつの弓形沈降帯が罹病 植物汁液に対して認められた。

$\mathrm{aC}-\mathrm{DB}(3, \mathrm{a})$ は $\mathrm{DB}, \mathrm{HB}$ とは全く反応せず， $\mathrm{DW}$ と $\mathrm{HW}$ に各 1 本, $\mathrm{DC}$ と $\mathrm{HC}$ とに各 4 本ずつの沈降 帯が認められたが, aC-HB (3, d) では DB, DW 拉 よび DC にさらに 1 本ずつの弓形の沈降帯が見られ た。

$\mathrm{aC}-\mathrm{DW}(3, \mathrm{~b})$ では 3 本の泌降帯が抗原と抗 血清 との中間部に生じ, $\mathrm{aC}-\mathrm{HW}(3, \mathrm{e})$ ではさらに DB, $\mathrm{DW}$ および DC に対して鋭利な三日月形の細長い沈 降带を生じたが，これら沈降帯は末端にて交さするこ となく同一反応系と考えられた。

$\mathrm{aC}-\mathrm{DC}(3, \mathrm{c})$ では完全吸収を示し, 全く沈降带が 認められなかつたが, $\mathrm{aC}-\mathrm{HC}(3, \mathrm{f})$ では罹病植物汁 液に対し反応が認められた。

以上より見ると罹病植物汗液をもつて吸収した抗血 清にはウイルス抗体の存在が認められなかつたが, 健 全植物汁液をもつて吸収した場合にはウイルス抗体は 吸収されず，罹病植物汁液との反応が認められた。

植物タンパクに対する抗体は免疫に用いた植物と同 一の健全植物にて吸収した場合に完全に吸収された。

\section{実 験 2}

前実験同様飞 $\mathrm{uB}, \mathrm{uW}$ 抽よび $\mathrm{uC}$ 抗血清を 6 種の 粗汗液抗原 (DB, DW DC, HB, HW および $\mathrm{HC}$ )
にてそれぞれ吸収し，各吸収血清について前実験同様 にして交さ反応を行なつた。結果はFig. $4 \sim 6$ の通り である。

uB-DB $(4, a), u B-D W(4, b), u B-D C(4, c)$, $\mathrm{uW}-\mathrm{DB}(5, \mathrm{a}), \mathrm{uW}-\mathrm{DW}(5, \mathrm{~b})$ および uC-DC (6, c）の6 種の吸収血清をそれぞれ中心としたすべての 反応基には全く反応が認められず，これらの吸収血清 では抗体が完全に吸収されたものと考兄られた。一 方, uB-HB (4, d), uB-HW (4, e), uB-HC $(5, f)$, $\mathrm{uW}-\mathrm{HB}(5 \mathrm{~d}), \mathrm{uW}-\mathrm{HW}(5, \mathrm{e})$ 㧊よび uC-HC $(6, \mathrm{f})$ の 6 種の吸収血清をそれぞれ中心とする反応基では, 罹病植物汁液（DB, DW および DC）に対してのみ 1 本の抗原側に凹形の沈降带を生じた。

$\mathrm{uW}-\mathrm{DC}(5, \mathrm{c})$ にては DB, HB, DW および $\mathrm{HW}$ 飞各 2 本ずつ, いずれも抗原, 抗血清の中央江直線状 沈降帯を生じ, uW-HC $(5, \mathrm{f})$ にてはこれら沈降帯の 他に，罹病植物抗原に対して各 1 本ずつ抗原側に出形 の細い弓形の沈降带を生じた。 $\mathrm{uC}-\mathrm{DB}(6, \mathrm{a})$ 飞対し ては DC 拈よび HC 飞各 1 本の直線状范降带が認め られ，uC-HB (6, d) ではこのほか DB，DW および $\mathrm{DC}$ との間に各 1 本ずつの弓形の沈降帯が認められ た。

uC-DW (6, b) を中心位置とした反応基に执いて, DC 扔よび HC 飞対してのみ, 抗原, 抗血清の中間 部に直線状の范降帯が 1 本ずつ認められ, 一方 $\mathrm{uC}$ HW $(6, \mathrm{e})$ 飞颃いてはこの他檌病植物抗原に対し て弓形の沈降带が 1 本ずつ生じた。

\section{実 験 3}

実験 1 おっよび実験 2 亿用いた 36 種の吸収血清に対し て，分画遠心法による純化抗原を用いて交さ反応を行 なつた。供試抗原は PDB, PHB, PDW, PHW, PDC および PHC の 6 種である。

この結果, 罹病植物抗原による吸収血清はすべての 純化抗原に対して反応が見られなかつた。また健全植 物抗原にて吸収した吸収血清は, 罹病植物の純化液 (PDB，PDW 叔よび PDC) に対してのみ1本ずつの 沈降带を生じたが，これらはすべて抗原側に四形の鋭 利な三日月形または弓形の沈降带であつた。また健全 植物の純化液 (PHB, PHW 拈よび PHC) 飞対して は反応が認められなかつた。

\section{実 験 4}

$\mathrm{aB}, \mathrm{aW}$ および $\mathrm{aC}$ 抗血清を分画遠心法による 6 種 の純化抗原 (PDB, PHB, PDW, PHW, PDC 㧊よび PHC) にてそれぞれ吸収し, 各吸収血清について実験 を行なつた。 
この結果, 罹病植物の純化液にて吸収した吸収血清 はすべての罹病植物抗原に対して弓形沈降帯が認めら れずまた健全植物の純化液にて吸収した吸収血清は 末吸収抗血清と同一の反応を示した。

\section{実 験 $\mathbf{5}$}

$\mathrm{uB}, \mathrm{uW}$ および uC 抗血清を実験 4 と同様にして 吸収した各吸収血清について実験を行なつた。

この結果, 罹病植物の純化液によつて吸収した吸収 血清を中心とするすべての反応基に沶いて，罹病植物 粗汁液に対して沈降帯が出現せず，この抗体が完全に 吸収されたことを示した。健全植物の粗汁液にて吸収 した吸収血清は，未吸収血清と同じ反応を示した。

\section{IV. 考察}

オオムギ斑葉モザイク病ウイルス汁液（粗汁液また は一部純化液）を用いて調製した抗血清は，ウイルス に対する抗体のほかに植物成分に由来すると考光られ る数種の抗体が含まれていることが, Ouchterlony 法 に基づく寒天ゲル中沈降反応の 結果認められた ${ }^{7,9) 。 ~}$ これらの抗原の解析のため, 種々の抗原によつて抗血 清の吸収を行なつて，各吸収血清について交さ反応を 試みた。この結果, 免疫原の異なる 6 種の抗血清のい ずれに捈いても，免疫原に用いた罹病植物と同種の健 全植物汁液で吸収すると，植物の種類に関係なく罹病 植物粗汁液拉よびその純化液に対して常に抗原側に近 く凹形の鋭利な三日月形あるいは弓形の沈降帯 1 本を 生じた。しかし健全植物粗汁液扣よびその純化液に対 しては全く沈降帯が出現しなかつた。これは uB 抗血 清を除く 5 種の抗血清中に含まれる植物成分に由来す る抗体が，免度原に用いた植物と同一植物の持つ抗原 によつて吸収され，ウイルス抗原に対する抗体のみを 含むことを示するのである。各抗血清を免疫原に用い た植物と同種の罹病植物粗汁液で吸収した吸収血清 は,すべての抗原に対して反応を示さず, 完全吸収を 示した。また免疫原と同種の罹病植物純化液で吸収し た吸収血清は，植物の種類にかかわらず，䍜病および 健全両植物汁液に対して同一の反応を示し，抗原と抗 血清のほぼ中間の寒天ゲル中に沈降帯を生じた。これ はウイルス抗体が完全に吸収されたことを示すものと 考えられる。

このウイルス抗体の吸収は免疫原に用いた植物と異 なる䍜病植物粗汁液およびその純化液をもつて吸収し た場合にも常に認められたが，健全植物の粗汁液およ びその純化液にて吸収した場合には認められなかつ た。抗血清と抗原とのほぼ中間の寒天ゲル中に出現す
る沈降帯は, 上述のよ5に同種植物の粗汁液による吸 収によつて消失したが，時には異種植物の粗汁液によ つても吸収されることがあり，植物の種類が異なる場 合にもウイルス抗原のほかにいくつかの植物成分に由 来すると考えられる抗原に共通抗原が存在することが 認められた。

ウイルスによる沈降帯がかならずしも単一でなく， 寒天ゲル中に 2 本以上の沈降帯が認められることがあ るといわれているが，その原因はかなり複雑のようで ある ${ }^{1,3,6,11)}$ 。しかし私共の行なつた実験ではウイルス タンパクによる沈降带は常に単一であつた。

以上の結果より考察して $\mathrm{DB}, \mathrm{DW}$ および $\mathrm{DC}$ の 3 種の粗汁液中に含まれるウイルス抗原を $\mathrm{VB}, \mathrm{Vw}$ 执よび Vc とし，それ以外の植物成分に由来する抗 原を $\mathrm{B}_{1}, \mathrm{~B}_{2}, \cdots \cdots, \mathrm{W}_{1}, \mathrm{~W}_{2}, \cdots \cdots$ 拉よび $\mathrm{C}_{1}, \mathrm{C}_{2}, \cdots \cdots$ と考えると, これらの汁液を免疫原として得られた抗 血清中に含まれる抗体はそれぞれ $\mathrm{vb}, \mathrm{vw}$, 小よび ve， ならびに $b_{1}, b_{2}, \cdots \cdots, w_{1}, w_{2}, \cdots \cdots$ および $c_{1}, c_{2} \cdots \cdots$ とな る。ところが抗原 $\mathrm{VB}, \mathrm{Vw}$ および $\mathrm{Vc}$ は抗体 $\mathrm{vb}, \mathrm{Vw}$ および ve のいずれとも同様の交さ反応を示し，乙か も沈降帯がそれぞれ末端で融合することから，これら による反応は全く同一の抗原抗体系であると考えられ る。すなわちウイルス抗体については $\mathrm{vb}=\mathrm{vw}=\mathrm{vc}=$ $\mathrm{v}$, したがつてウイルス抗原は $\mathrm{V}_{\mathrm{B}}=\mathrm{Vw}=\mathrm{Vc}=\mathrm{V}$ と 考えられる。

つぎに異種植物の粗汁液による吸収試験の結果より 考えると, $\mathrm{aB}$ 抗血清中に含まれる植物成分に由来す ると考えられる少なくとも 4 種の抗体 $\left(\mathrm{b}_{1}, \mathrm{~b}_{2}, \mathrm{~b}_{3}\right.$ 特よ び $\left.b_{4}\right)$ は，W抗原によりその5ちの 3 種が吸収され 1 種が吸収されず残る。すなわち， $b_{1}, b_{2}, b_{3}$ 执よび $b_{4}$ のちちの 1 種（仮りに $b_{1}$ ） はW抗原によるものと 共通でない抗体である。これをa とすると $b_{1}=a$ であ る。他の 3 種の抗体はB抗原中に含まれる少なくとも 5 種の抗原の5ちのいずれかの 3 種と反応する。また $\mathrm{aW}$ 抗血清中に含まれる少なくとも5つの抗体 $\left(\mathrm{w}_{1}\right.$, $\mathrm{w}_{2}, \mathrm{w}_{3}, \mathrm{w}_{4}$ 扤よび $\mathrm{w}_{5}$ ) は $\mathrm{W}$ 抗原と反応するとともに B抗原の 3 種および C抗原の 1 種に対して反応する。 しかして吸収試験の結果からC抗原に対する 1 種は, B抗原に対して共通なる 3 種を除いた残りの 2 種のう ちの 1 種である。そこで $\mathrm{b}_{2}, \mathrm{~b}_{3}$ 括よび $\mathrm{b}_{4}$ は $\mathrm{w}_{1}, \mathrm{w}_{2}$ および $\mathrm{w}_{3}$ のそれぞれ 1 つと共通であり，残りの $\mathrm{w}_{4}$ および $\mathrm{w}_{5}$ のうちの 1 つが $\mathrm{c}_{1}, \mathrm{c}_{2}, \mathrm{c}_{3}$ 执よび $\mathrm{c}_{4}$ のうち の 1 つと共通であるので $\mathrm{b}_{2}=\mathrm{w}_{1}, \mathrm{~b}_{3}=\mathrm{w}_{2}, \mathrm{~b}_{4}=\mathrm{w}_{3}$, $\mathrm{w}_{4}=\mathrm{c}_{1}$ とすると, これらの間に次の関係が成り立 ?。 
$b_{1}=a, b_{2}=w_{1}=b, b_{3}=w_{2}=c, \quad b_{4}=w_{3}=d, \quad w_{4}=c_{1}$ $=\mathrm{c}, \mathrm{w}_{5}=\mathrm{f}, \mathrm{c}_{2}=\mathrm{g}, \mathrm{c}_{3}=\mathrm{h}, \mathrm{c}_{4}=\mathrm{i}$

したがつて私共の行なつた実験に打ける各抗血清中 の抗体組成は少なくとも

$$
\begin{aligned}
& a B=v, a, b, c, d \\
& a W=v, b, c, d, e, f \\
& a C=v, e, g, h, i
\end{aligned}
$$

でありこれを各抗原について考えると

$$
\begin{array}{ll}
\mathrm{DB}=\mathrm{V}, \mathrm{A}, \mathrm{B}, \mathrm{C}, \mathrm{D} & \mathrm{HB}=\mathrm{A}, \mathrm{B}, \mathrm{C}, \mathrm{D} \\
\mathrm{DW}=\mathrm{V}, \mathrm{B}, \mathrm{C}, \mathrm{D}, \mathrm{E}, \mathrm{F} & \mathrm{HW}=\mathrm{B}, \mathrm{C}, \mathrm{D}, \mathrm{E}, \mathrm{F} \\
\mathrm{DC}=\mathrm{V}, \mathrm{E}, \mathrm{G}, \mathrm{H}, \mathrm{I} & \mathrm{HC}=\mathrm{E}, \mathrm{G}, \mathrm{H}, \mathrm{I}
\end{array}
$$

なる抗原組成が考えられる。

同様にして $\mathrm{uB}, \mathrm{uW}$ および $\mathrm{uC}$ 抗血清について抗 原分析を試みた。 $\mathrm{uB}$ 抗血清は $\mathrm{v}$ 抗体のみを含み, $\mathrm{uW}$ 抗血清はB抗原に対して少なくとも 2 本, W抗原 に対しても最少 2 本の沈降带を生じ, しかも 2 本とも BおよびW抗原に共通であつた。これは C 抗原に対し ては共通でなく, したがつてW抗原と反応するのはb, $\mathrm{c}, \mathrm{d}$ のちのいずれかの 2 種であると考えられる。こ れを仮りにb拈よび c とする。 uC 抗血清に抹いては $\mathrm{C}$ 抗原に対してはv抗体のほかに少なくとも 1 種の抗 体を含むことが認められた。これはW抗原と反応しな いところから e ではなくて, g, h, i の らちの 1 種であ り, しかも抗血清に近い位置にあつた。今仮りにこれ を $\mathrm{g}$ とると，これらの関係はつぎのようになる。

$$
\begin{aligned}
& \mathrm{uB}=\mathrm{v} \\
& \mathrm{uW}=\mathrm{v}, \mathrm{b}, \mathrm{c}
\end{aligned}
$$$$
\mathrm{uC}=\mathrm{v}, \mathrm{g}
$$

したがつて抗原分析の結果は次のように推定される。

（但し一は抗原認められず）

$$
\begin{array}{ll}
\mathrm{PDB}=\mathrm{V} & \mathrm{PHB}=- \\
\mathrm{PDW}=\mathrm{V}, \mathrm{B}, \mathrm{C} & \mathrm{PHW}=\mathrm{B}, \mathrm{C} \\
\mathrm{PDC}=\mathrm{V}, \mathrm{G} & \mathrm{PHC}=\mathrm{G}
\end{array}
$$

な拈 $\mathrm{uW}$ 抗血清は抗体 $\mathrm{v}, \mathrm{b}, \mathrm{c}$ を含み, PDW は抗 原 $\mathrm{V}, \mathrm{B}, \mathrm{C}$ を含むものと推定されるが，実際にはこの 抗血清と抗原との反応の結果, ウイルス抗原による沈 降带のみが生じ, 正常植物成分による沈降帯が認めら れなかつた。これは純化により正常植物成分がきわめ て少なくなり, 免疫原として反復注射を行なつた場合 には抗体の産生を見るが，抗原としては濃度が低いた めに反応が認められなかつたものと考えられた。

以上の結果の示すように, 本実験で行なつた硫安塩 析法による純化ではウイルス汁液を完全に純化するこ とができず，健全植物成分に由来する抗原物質を多く 含むが, 分画遠心法によつてもなおこれらの一部分を
含み，完全にウイルスが純化されない場合があつた。 ごく少量のこのような抗原物質の存在でも家躳に反復 注射すると抗体を生ずるものと考えられる。とくにコ ムギ怙よびトウモロコシでその傾向が強かつた。これ らの物質は $2 / 5$ 飽和以上の硫安塩析で大部分が沈殿す るが，12,000×g，30 分間の遠心分離で沈殿せず, $80,000 \times \mathrm{g}, 90$ 分間で一部が沈殿する。またこの物質 は家秉の血清中に容易に抗体を産生し，さらに 1.5\% の寒天ゲル中をすみやかに拡散し，抗原と抗血清との 間隔が $1 \mathrm{~cm}$ である昜合には48時間以内に両者の中間 部に沈降带を生ずるきわめて微細な粒子であり，罹 病, 健全両植物に共通して存在することが認められ, 正常植物タンパクと考えられる。本実験ではオオムギ の中には最低 4 種の異なつたこのような抗原物質が含 まれ、コムギは最低 5 種, トウモロコシには最低 4 種 がそれぞれ認められた。このうちオオムギ, コムギ, コムギとトウモロコシの間には共通抗原が認められた が，オオムギとトウモロコシとの間には共通抗原の存 在が認められなかつた。しかしこれらの関係について はさらに実験を行なわなければならない。

Moorhead ${ }^{5)}$ はトウモロコシ，力ボチャ，コムギ， オオムギ, タバコ拈よびトマトの 6 種の植物の抗血清 について, 補体結合反応, 寒天ゲル中沈降反応扣よび 免疫電気泳動法を用いて交さ反応を行なつた結果, 各 抗原のほとんどが最低 2 種以上の異種抗血清と反応す ることを認めた。これらのうち，オオムギとコムギと の抗原, 抗血清間の反応は一般に強く, その他の植物 の抗原・抗血清間では反応が弱かつたということであ る。福島・松井 ${ }^{2)}$ は作物の類縁, とくに品種の分析に Ouchterlony 法の変法を考案して寒天ゲル中沈降反応 を行なつている。

ウイルスに対する反応の結果と考えられる沈降帯 が，常に抗原側に凹形の弯曲した形態をとることは次 のように考えられる。すなわち BSMVは長さ $127 \mathrm{~m} \mu$ ， 幅 $25 \mathrm{~m} \mu$ の桿状粒子10) であり, 形態的には寒天ゲル 中での拡散能力がかなり低いものと考えられる。一 方, 抗血清中の抗体は通常 $\gamma$-globulin の部分に含ま れ，これは長さ $27.4 \mathrm{~m} \mu$ ，幅 $3.7 \mathrm{~m} \mu$ の棛円体粒子で あつてウイルス粒子に比べきわめて小さく，寒天ゲル 中での拡散速度は比較的速いものと考えられる。した がつてこの抗原および抗体が同時に両方の凹みの周縁 の壁から寒天ゲル中に拡散して行く場合に，互いに最 適比濃度になる位置で反応して沈降帯が生ずるとする と，それは Korngold ${ }^{4)}$ も述べているように，抗原と 抗血清とを入れた両方の凹みの中間より抗原側にあつ 
て,しかも抗原側に四形の弯曲した沈降帯として認め られるものと考えられる。

いま，抗体と抗原がそれぞれ寒天中を一定速度 a お。 よび b で拡散して反応すると考光, 両方の山みの中心 点の座標をそれぞれ $(10,0)$ および $(-10,0)$ と 特くと, $\mathrm{t}$ 時間後の拡散の結果考光られる円の方程式 は

抗体側では $(x-2 r)^{2}+y^{2}=(r+a t)^{2}$

抗原側では $(x+2 r)^{2}+y^{2}=(r+b t)^{2}$

$$
\text { (ただし } \mathrm{r}=5 \text { ) }
$$

であり，（1）执よび（2）の交点の軌跡を求めるこ とにより沈降帯の形態を知ることができる。ここでa とbとは直接知ることが困難であるので, 沈降帯出現 をもつてその座標とすると, 最初の沈降帯がほぼ 48 時間後に両方の凹みのほぼ中間に生ずることから, 抗 体の拡散速度 a はほぼ $5 / 48 \mathrm{~mm} / \mathrm{hr}$, 同様にしてウイル ス抗原による沈降帯は約 96 時間後に生じ, その時の 抗原の移動距離は約 $2 \mathrm{~mm}$ であるので, 拡散速度はほ ぼ $1 / 48 \mathrm{~mm} / \mathrm{hr}$ とすることができる。抗体と抗原が最 初に接するのは $\mathrm{t}=\frac{2 \mathrm{r}}{\mathrm{a}+\mathrm{b}}$ すなわら 80 時間後で交 点は 2 つの凹みの中心を結ぶ直線上にあり，座標は $\left(\frac{b-a}{a+b} r ， 0\right)$ である。時間の経過に従つて上下に対 称に曲線ができてくる。つまりこの曲線にしたがつて 反応が生ずると考えられる。この曲線を表わす式は

(1) 扣よび (2) から $\mathrm{t}$ を消去して

$a \sqrt{(x+2 r)^{2}+y^{2}}-b \sqrt{(x-2 r)^{2}+y^{2}}=(a-b) r \cdots(3)$

この曲線は円とはならないが最初に接する点での曲 率半径を( 3 ) の式から求めると

$$
\frac{(a+3 b)(3 a+h)}{3\left(a^{2}-b^{2}\right)} r
$$

曲率円の中心の横座標は

$$
-\frac{2\left(3 \mathrm{a}^{2}+3 \mathrm{~b}^{2}+2 \mathrm{ab}\right)}{3\left(\mathrm{a}^{2}-\mathrm{b}^{2}\right)} \mathrm{r}
$$

となる。 $\mathrm{r}=5, \mathrm{a}=\frac{5}{48}, \mathrm{~b}=\frac{1}{48}$ であるから, 曲率円 は中心 $(-12.5,0)$, 半径 8.89 となる。このこと は最初に接する点の附近では曲線は近似的に上に求め た円弧となると考えられる。抗体と抗原との拡散速度 の差が小さくなるにしたがつて曲率円の半径は大きく なり，曲線は次第に直線に近くなる。

実際に認められる沈降帯はこれとよく一致している が,この沈降帯の形が最初の交点である中央部に括い てやや幅広く，両端は次第に細くなる鋭利な三日月形 を示すのは次のように考兄られる。すなわち，抗体の 拡散速度がウイルスのそれより大きく早く抗原側に達 し, 拡散半径の増加にともなつて拡散量が低下する。
したがつて最初に接した部分に执いて最も沈降帯が多 く, 沈降帯は明瞭でやや幅広く, その後次第に沈降量 が减じて沈降帯は細く次第に不明瞭となり,さらには 全く反応が認められなくなる。

正常植物タンパクに由来する沈降帯が抗原と抗血清 とのほぼ中間にあり，しかもほとんど直線状であつた のはこれらの抗原物質が抗体とほぼ同等の拡散速度を 有するものであるためと思われる。今かりに抗体と全 く同じ拡散速度を有するものと考えると, $a=b$ とて

$$
\left\{\begin{array}{l}
x=0 \\
y= \pm \sqrt{(r+a t)^{2}-(2 r)^{2}}
\end{array}\right.
$$

つまり交点は常に $\mathrm{x}=0$, すなわち $\mathrm{y}$ 軸上にあり, 時 間 $\mathrm{t}$ によつて正負の両方向に同様に延びて行くものと 考学られる。したがつて沈降帯は同様に拡がつて行く 2 円の根軸上にあり, 直線状の沈降帯として認められ る。この場合にも両端において次第に沈降量が減じ, さらに全く反応が認められなくなる。

\section{V. 摘 要}

1. 供試抗 BSMV 血清は複雑な抗原抗体系を有す ることが寒天ゲル中沈降反応の結果認められたが, 同 種健全植物汁液による吸収を行なつた吸収血清は常に 単一抗原抗体系を示し, 寒天ゲル中に 1 本の沈降帯が 認められた。

2. 吸収血清に見られた 1 本の沈降帯は常に抗原を 入れた凹みのすぐ近くに生じ，両端が抗原側に弯曲し た鋭利な三日月形あるいは弓形であつた。この沈降带 は抗血清を罹病植物粗汁液めるいはその純化液で吸収 した場合に消失し，ウイルス抗原による反応の結果と 考えられた。

3. 他のすべての沈降帯は抗原を入れた四みと抗血 清を入れた凹みのほぼ中間の寒天中に直線状に生じ, これらの抗原物質はウイルス抗原よりも寒天中をより 速く拡散する正常植物タンパクと思われた。

4. 本実験に打ける硫安塩析法による純化免疫原で 調製した抗血清のらち，オオムギを用いたものでは少 なくとも 4 種，コムギでは少なくとも 5 種，トウモ口 コシでは少なくとも 4 種の植物成分に由来する抗体を 含さことが認められた。

5. 吸収試験の結果, 各罹病植物に共通な抗原物質 はウイルスなることが認められた。

6. ウイルス抗原による沘降帯は抗原と抗体との拡 散の結果考えられる 2 円の交点の軌跡上にあると考え られた。

(1962. 4. 2 受理) 


\section{引用 交 献}

1. Bancroft, J. B. and Kaesberg, P. (1960). Biochim. Biophys. Acta 39 : 519-528.

2. 福島栄二・松井 健 (1959). 農及園 $34: 1789$ 1794.

3. Kleczkowski, A. (1957). J. Gen. Microbiol. $16: 405-417$.

4. Korngold, L. and Leeuwen, G. van (1956). J. Immunol. $78: 172-177$.

5. Moorhead, E. L. (1960). Phytopath. 50 :646647 (Abst.).
6. Moorhead, E. L. (1961). Virology $13: 249-255$.

7. 村山大記 - 根本正康 - 横山竜夫 (1959). 日植病報 $24: 30$ (講要).

8. 村山大記 - 横山竜夫 (1962), 日植病報 $27: 38-44$.

9. 村山大記 - 横山竜夫 (1962). 日植病報 $27: 45-49$.

10. 四方英四郎・村山大記 - 根本正康(1959)。日植病 報 $24: 30$ (講要).

11. van Slogteren, D. H. M. (1954). in Proceedings of the Second Conference on Potato Virus Diseases. Lisse-Wageningen, 1954. pp. 45-50.

\section{Summary}

1. This paper deals with the resuts of cross-absorption tests of antisera for barley stripe mosaic virus, purified by ultra-centrifugation or by salting-out with ammonium sulfate, from juices of diseased barley, wheat, and corn plants. Use was made of the agar-gel diffusion method. When the antisera had been absorbed by homologous healthy plant juices, there always appeared a single precipitation band against diseased plant juices, either homologous or heterologous.

2. This precipitation band was usually located near the outer hollows filled with the antigens, and curved towards both ends to show a sickle or bow shape. As this band disappeared when the antisera had been absorbed by diseased plant juice or by purified virus suspension, this precipitation pattern was considered to represent a specific reaction between the virus-antigen and its corresponding antibody.

3. All other precipitation bands were formed usually midway between two hollows filled with the antigen and the antiserum. Because the antigenic components in these reactions diffused more rapidly in the agar layer than did the virus-antigen, these components were considered to be relatively small particles, and seemed to be normal plant proteins.

4. It was recognized that antisera prepared with barley plant juices purified by salting-out with ammonium sulfate contained at least four distinguishable antibcdies, while antisera prepared with wheat and corn plant juices contained five and four distinguishable antibodies, respectively, all of which were considered to be antibcdies against normal plant proteins.

5. In the absorption tests, no antigen-antibody system common to normal plant proteins of the three different host plants, except the virus-antigen and its corresponding antibody, have been found by the use of agar-gel diffusion tests.

6. The precipitation band resulting from the reaction between the virus and its corresponding antiserum was considered to occur on the locus of two intersections of two circles representing the diffusion fronts of both antigen and antibody, and mathematical equation for the locus was obtained. 


\section{Explanation of Plates}

Fig. 1. Comparison of precipitation patterns obtained by gel-diffusion with antiserum aB absorbed by six different antigens, $\mathrm{DB}(\mathrm{a}), \mathrm{DW}(\mathrm{b}), \mathrm{DC}(\mathrm{c}), \mathrm{HB}(\mathrm{d}), \mathrm{HW}(\mathrm{e})$, and $\mathrm{HC}(\mathrm{f})$, respectively, with which the outer hollows were filled. Absorbed-sera are represented by hatched and antigens by open circles. Virus precipitation zones are curved, while zone of precipitation by non-virus normal proteins are straight lines.

Fig. 2. Comparison of precipitation patterns obtained with antiserum aW absorbed as above.

Fig. 3. Comparison of precipitation patterns obtained with antiserum aC absorbed as above.

Fig. 4. Comparison of precipitation patterns obtained with antiserum $u B$ absorbed as above.

Fig. 5. Comparison of precipitation patterns obtained with antiserum $u W$ absorbed as above.

Fig. 6. Comparison of precipitation patterns obtained with antiserum $\mathrm{uC}$ absorbed as above.

\section{文献紹介}

\section{ヨーロッパに私けるムギ類黄さび病菌の race}

E. Fuchs : Der Stand der Rassenspezialisierung beim Gelbrost Puccinia glumarum (Schm.) Erikss. et Henn. in Europa. Nachrichtenbl. Deutsch. Pflanzenschutzd. (Braunschweig) $8: 87 \sim 93,1956$.

1956 年 2 月に西ドイッ Braunschweig で第 1 回 ヨーロッパ黄さび病会議が開催され, 色々の点につ いて討議がなされたようであるが，特に寄生性の分 化についての問題をとりまとめたのがこの報告であ る。これによると，それまで Straibによつて実験， 新しい race として認め, 未発表であつたものを, race 54 として新たに認め, その判別品種上での反 応を記載している。また Manner (1950) が明らか にした race $M$ を race 57 として記載しており, 現在まで知られている race とその判別品種上での 反応をわかりやすくとりまとめてある。同時にま た，寄生性分化についての実験上の諸注意があげら れて拈り,さらにオオムギ黄さび病菌の判別品種と しては, Fong Tien, Heils Franken, Eskanzuela, Bavaria, Peragis, Schwarze Zweizeilige を用いる が，これだけではな怙不充分で，新しい判別品種を 探す必要があるとしている。

\section{Botrytis cinerea ¿ Botrytis fabae Кよ} るソラマメの感染

Deverall, B.J. and R. K. S. Wood : Infection of bean plants (Vicia fabae L.) with Botrytis cinerea and B. fabae. Ann. appl. Biol. 49:461 472, 1961.

ソラマメの赤色斑点を起こす病原菌はイギリスで は Botrytis cinerea Pers. が最も重要であり, スペ イン，日本では B. fabae Sard. とされている。こ こでは $2 つ の$ 病原菌の感染力を比較した。赤色斑点 でとどまる“non-aggressive phase” と環境が適す るときは“aggressive phase”があるが, 後者で植 物体は短期間に枯死し, 胞子形成もこのような病斑 にだけみられる。接種源の胞子濃度を増すと病斑数 は増し, 古い葉は若い葉より, $\mathrm{Ca}$ 久乏や葉面を軽 くこすつた葉などでは病斑の形成が早い。 B. cinerea は接種した大部分の胞子が発芽するにかかわ らず, B. fabae の方が病斑数が 1.9 4.1 倍多 く, 病斑のひろがりも早かつた。B. fabae は aggressive lesion への移行が容易で, 明らかに病原 性が強い。

（高梨 和雄）

（梶原，敏宏） 
Plate I

Fig. 1

(DB $\mathrm{HC}$

(DB $\mathrm{HC}$

(DW $(-\mathrm{BW})$

(DC) $\mathrm{HB}$

a

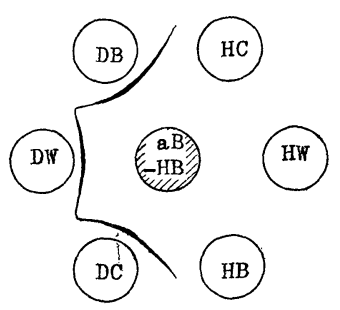

d

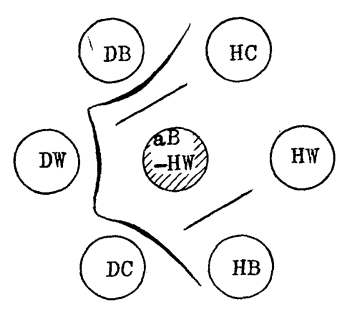

e
(DB $\mathrm{HC}$

(DW)

(DC) $\mathrm{HB}$

c

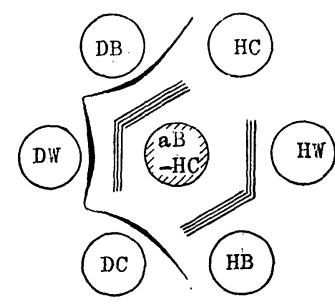

f

Fig. 2

(DB $\mathrm{HC}$ (DB

(DW (DC) $\mathrm{HB}$

a

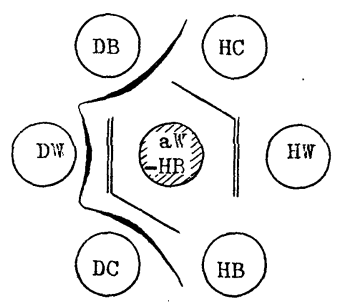

d
(DW EW

(DC) $\mathrm{HB}$

b

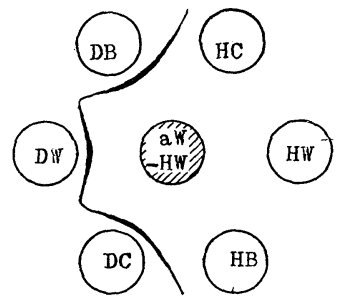

$e$
(DB $\mathrm{HC}$

(Dw $\mathrm{aw}$

(DC) (HB

c

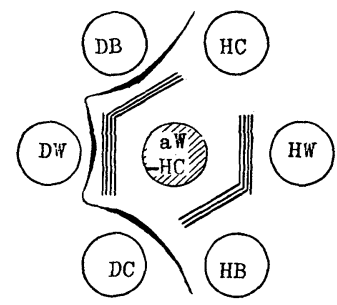

f 
Plate II

Fig. 3

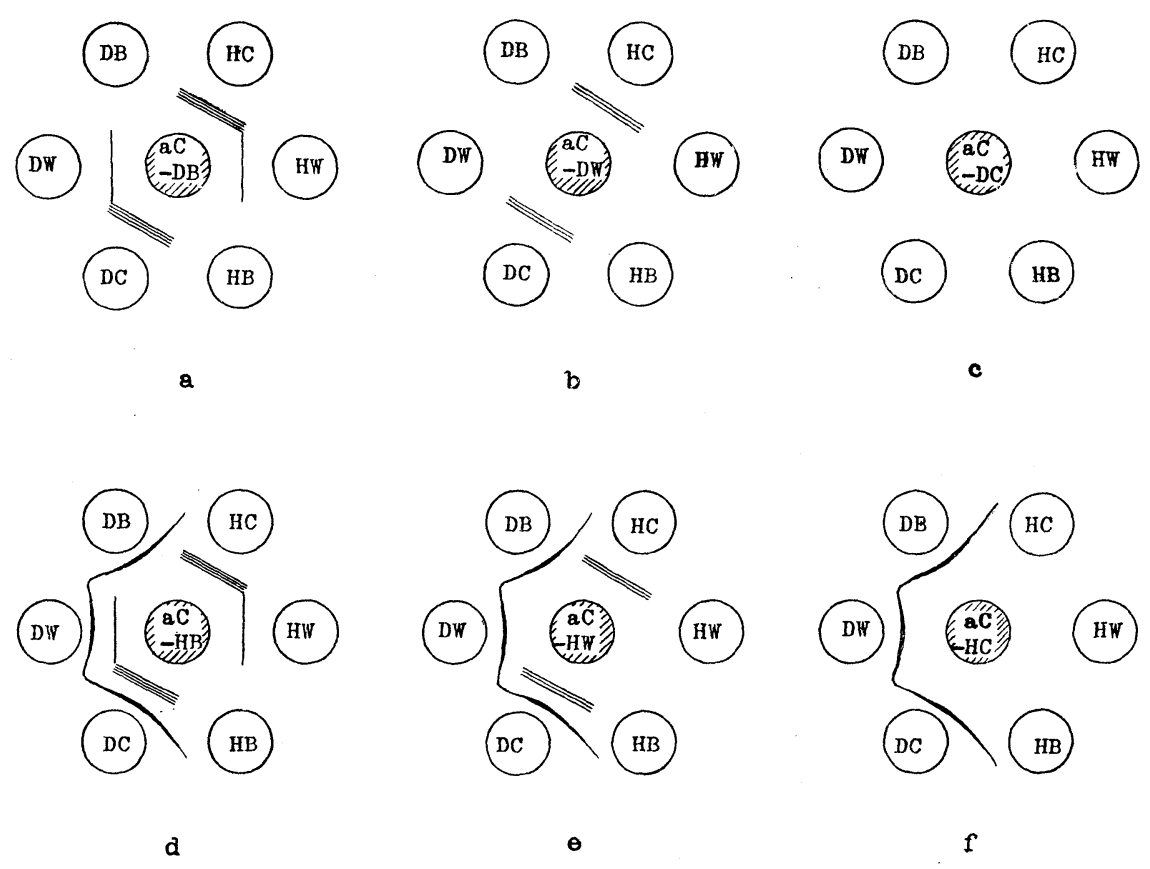

Fig. 4
(DB $\mathrm{HC}$
(DB $\mathrm{HC}$
(DB $\mathrm{HC}$

(DW) (DW

(DC) $\mathrm{HB}$

a

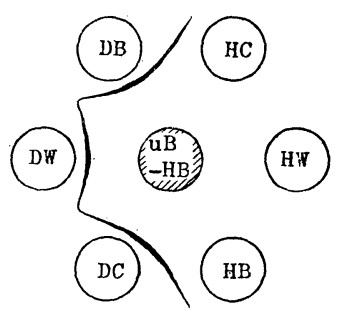

d
(DC)

b

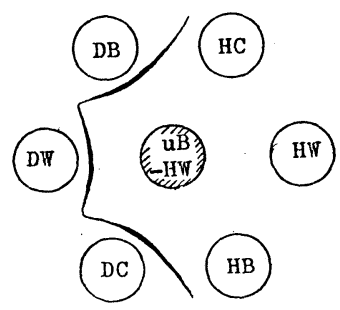

$\theta$
(DC)

c

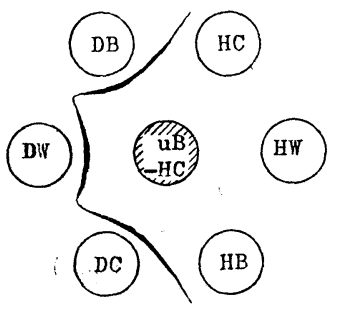

f 
Plate III

Fig. 5

(DB $(\mathrm{HC}$ (HC) $\mathrm{DB}$

(DW (DW D (DW
(DC)
(DC)
(DC $\mathrm{HB}$

a

h

c

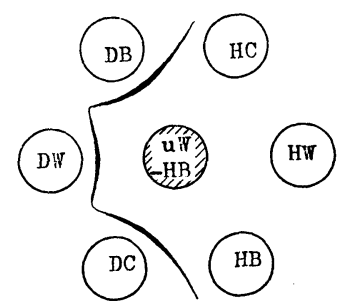

d

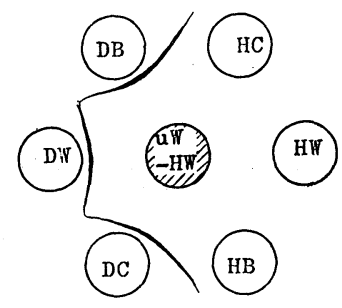

$\theta$

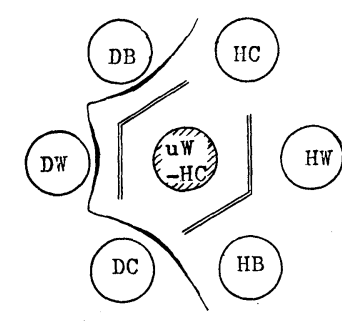

f

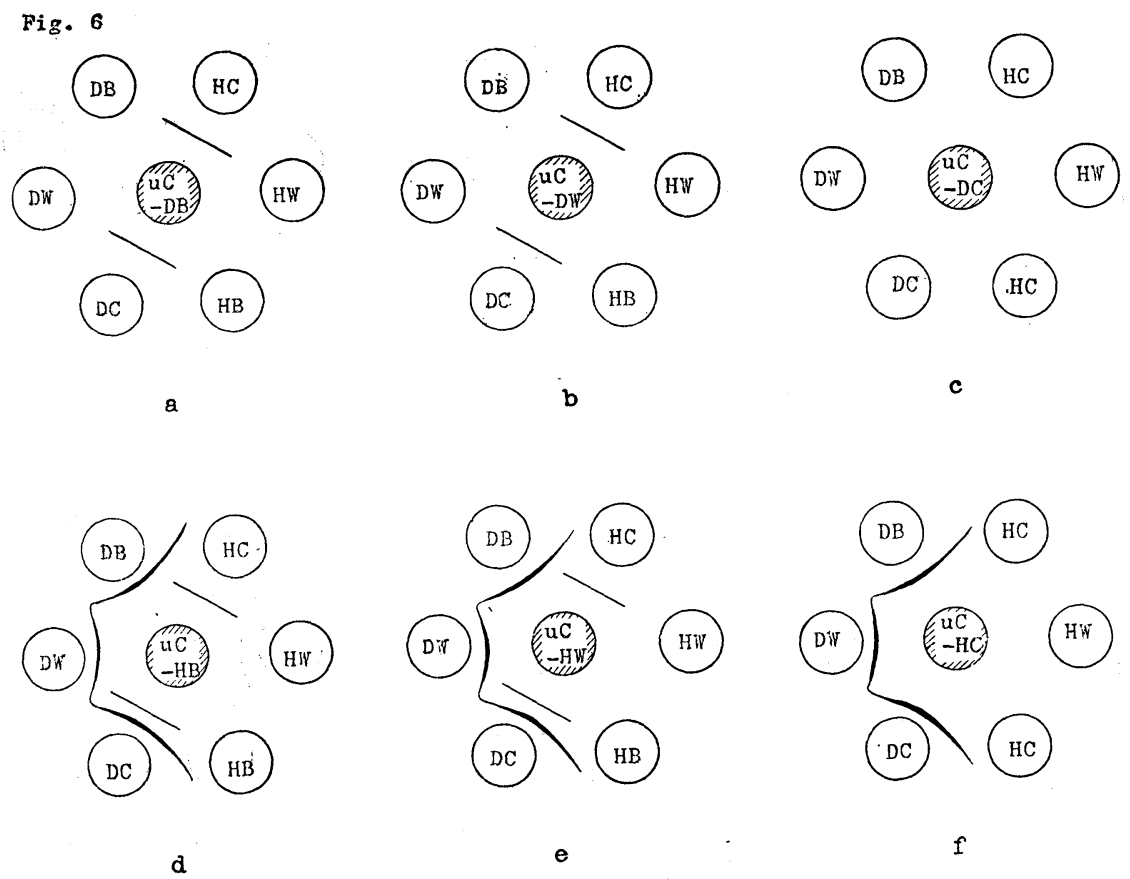

